Int. J. Electrochem. Sci., 13(2018) $8275-8294$

International Journal of

ELECTROCHEMICAL

SCIENCE

www.electrochemsci.org

\title{
Potentiometric and Conductometric study of complex formations between Norfloxacin and Some metal ions and Norfloxacin determination in Dosage Forms
}

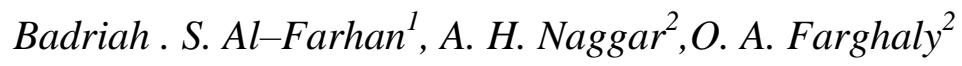 \\ ${ }^{1}$ Chemistry Department, Faculty of Girls for Science, King Khalid University, Abha, King Saudi \\ Arabia.KSA \\ ${ }^{2}$ Chemistry Department, Faculty of Science, Al-Azhar University, Assiut Branch, 71524, Assiut, \\ Egypt. \\ *E-mail: shahd|_bb@ hotmail.com
}

doi: $10.20964 / 2018.09 .43$

Received: 2 February 2018/ Accepted: 1 June 2018 / Published: 5 August 2018

\begin{abstract}
The determination of proton ligand association constants of Norfloxacin(NFX) with different metal ions viz; $\mathrm{Ti}(\mathrm{II}), \mathrm{Ba}$ (II), $\mathrm{Sr}(\mathrm{II}), \mathrm{Co}(\mathrm{II}), \mathrm{Zr}(\mathrm{IV}), \mathrm{La}(\mathrm{II}), \mathrm{Pb}(\mathrm{II}), \mathrm{Cr}(\mathrm{III}), \mathrm{Fe}(\mathrm{III})$ and $\mathrm{Sn}(\mathrm{II})$ by potentiometric and conductometric methods, at ionic strength $(\mu=0.01 \mathrm{M} \mathrm{NaCl})$ was investigated and the two logarithmic association constant values which calculated by the half $-\bar{n}$ method were 6.2 and 8.0. The stoichiometric of NFX-metal ion formed complexes was calculated to be $1: 1,1: 2$ and/or 1:3 metal to ligand ratios are formed depending on the nature of the ligand and/or metal ions. The effect of ionic strength on stability constant of NFX, with some different metal ions was studied.The stoichiometry of complexes formed in solution was confirmed by conductometric method.As well as, the species distribution $(\alpha)$ diagrams for NFX and their metal complexes which calculated as mole fraction $\alpha_{M L}$ and $\alpha_{M L 2}$, were discussed.Also simple, precise, rapid and low-cost potentiometric and conductometric methods for determination of NFX(in pure form) were performed using sodium hydroxide as titrant, at $25 \pm 1.0^{\circ} \mathrm{C}$. The calibration graph was linear from $0.32-2.87 \mathrm{mg} \mathrm{L}^{-1}$ with detection limit of $0.27 \mathrm{mg} \mathrm{L}^{-1}$, at SD was $<1.0$, and correlation coefficient (r) was calculated to be 0.9952.The proposed methods were successfully applied for NFXdetermination in pharmaceutical formulations (tablets and eye drops) with no interferences from usual excipients. The analytical results obtained by applying the proposed methods compared very favorably with those obtained by the official method such as United States Pharmacopoeia and British Pharmacopoeia. The Recoveries obtained of the proposed methods for determination of NFX in various tablet dosage forms were found to be in the range of 95.8 to $103.3 \%$, with standard deviations (SD) were within $0.16-0.24$ $(n=5)$.
\end{abstract}

Keywords:Norfloxacin, metal complexes, potentiometric and conductometric determination, Tablets, Eye drops. 


\section{FULL TEXT}

(C) 2018 The Authors. Published by ESG (www.electrochemsci.org). This article is an open access article distributed under the terms and conditions of the Creative Commons Attribution license (http://creativecommons.org/licenses/by/4.0/). 